\title{
Centrifugal Innervation of the Olfactory Bulb: A Reappraisal
}

\author{
Estelle E. in 't Zandt, ${ }^{1,2^{\wedge}}$-Hillary L. Cansler, ${ }^{1,2^{\wedge}}$ Heather B. Denson, ${ }^{1,2}$ and ${ }^{\circledR D a n i e l ~ W . ~ W e s s o n ~}{ }^{1,2}$
}

https://doi.org/10.1523/ENEURO.0390-18.2019

${ }^{1}$ Department of Pharmacology and Therapeutics and ${ }^{2}$ Center for Smell and Taste, University of Florida, Gainesville, FL 32610

\begin{abstract}
The inter-regional connectivity of sensory structures in the brain allows for the modulation of sensory processing in manners important for perception. In the olfactory system, odor representations in the olfactory bulb (OB) are modulated by feedback centrifugal innervation from several olfactory cortices, including the piriform cortex (PCX) and anterior olfactory nucleus (AON). Previous studies reported that an additional olfactory cortex, the olfactory tubercle (OT), also centrifugally innervates the $\mathrm{OB}$ and may even shape the activity of OB output neurons. In an attempt to identify the cell types of this centrifugal innervation, we performed retrograde tracing experiments in mice utilizing three unique strategies, including retrobeads, retrograde adeno-associated virus (AAV) driving a fluorescent reporter, and retrograde AAV driving Cre-expression in the Ai9-floxed transgenic reporter line. Our results replicated the standing literature and uncovered robustly labeled neurons in the ipsilateral PCX, AON, and numerous other structures known to innervate the OB. Surprisingly, consistent throughout all of our approaches, no labeled soma were observed in the OT. These findings indicate that the OT is unique among other olfactory cortices in that it does not innervate the OB, which refines our understanding of the centrifugal modulation of the OB.
\end{abstract}

Key words: centrifugal innervations; olfactory bulb; olfactory system; olfactory tubercle

\section{Significance Statement}

The perception of our environment relies on the distribution of sensory information throughout brain regions. This is true in the olfactory system wherein projections between olfactory centers, including feedback centrifugal input to the olfactory bulb $(\mathrm{OB})$, provide the basis for olfactory perception. Here, we show that one olfactory cortical structure, the olfactory tubercle (OT), is unique among olfactory cortices in that it lacks feedback projections to the OB. This "negative result" is important in that it refines current models for the circuitry of our olfactory system and challenges previous literature reporting such a pathway in fact exists.

\section{Introduction}

In our sensory systems, the initial steps of information processing are directed not only by bottom-up sources from the environment, but also by top-down inputs from higher-order structures (Kiselycznyk et al., 2006; Gilbert

Received October 5, 2018; accepted January 19, 2019; First published January 28, 2019.

The authors declare no competing financial interests.

Author contributions: E.E.Z., H.L.C., and D.W.W. designed research; E.E.Z., H.L.C., and H.B.D. performed research; E.E.Z., H.L.C., and D.W.W. analyzed data; E.E.Z., H.L.C., and D.W.W. wrote the paper. and Li, 2013; Terreros and Delano, 2015). This type of centrifugal modulation allows early sensory representations to be shaped by factors such as learning, and internal states including hunger and arousal (Lavin et al., 1959; Gervais and Pager, 1979; Sullivan et al., 1989;

This work was supported by National Institutes of Health National Institute on Deafness and Other Communication Disorders Grants R01DC014443 and R01DC016519 (to D.W.W.). E.E.Z. was supported by an undergraduate award from the University of Florida Center for Smell and Taste.

${ }^{\wedge}$ E.E.Z. and H.L.C. are equally first authors.

Acknowledgements: We thank members of the Wesson lab and M. Wachowiak for helpful discussions regarding this project. 
Wachowiak et al., 2009; Fletcher and Chen, 2010; Kato et al., 2012; Ross and Fletcher, 2018). Feedback projections may arise from neuromodulatory loci as well as cortical structures, and thus can have a wide range of effects on sensory representations and perception, including state-dependent sensory gating and experiencedependent plasticity (Shepherd, 1972; Petzold et al., 2009; Bajo et al., 2010; Devore and Linster, 2012; Smith et al., 2012; Rothermel et al., 2014; Terreros and Delano, 2015; Ogg et al., 2018). Major questions remain regarding the neural circuitry underlying centrifugal modulation.

In the olfactory system, odors detected in the epithelium are first processed in the olfactory bulb (OB; Schoppa and Urban, 2003; Ache and Young, 2005; Wachowiak and Shipley, 2006). Next, OB principal neurons called mitral and tufted cells convey information to one of several olfactory cortices, including the anterior olfactory nucleus (AON), piriform cortex (PCX), and the olfactory tubercle (OT), each of which is thought to play a specialized role in odor processing (Scott et al., 1980; Haberly, 2001; Brunjes et al., 2005; Gottfried, 2010; Wesson and Wilson, 2011; Wilson and Sullivan, 2011). Additionally, all of these structures are reported to send centrifugal inputs back to the OB (Shafa and Meisami, 1977; Kiselycznyk et al., 2006; Markopoulos et al., 2012; Rothermel and Wachowiak, 2014; Otazu et al., 2015), suggesting that each may contribute, perhaps in unique manners, to the modulation of early odor representations. For example, AON inputs to the OB are activated in odor-specific and state-dependent manners (Rothermel and Wachowiak, 2014). These AON inputs directly activate mitral and tufted cells and indirectly drive local inhibitory circuits, resulting in a widespread inhibition which is proposed to aid in suppressing OB background activity (Markopoulos et al., 2012). Similarly, activation of PCX inputs to the OB during odor stimulation enhances odor-evoked inhibition of mitral and tufted cells, though this occurs via different elements of the OB microcircuit (Boyd et al., 2012; Markopoulos et al., 2012). Further, PCX inputs to the OB target mitral cells, but not tufted cells (Otazu et al., 2015). Together these results indicate that feedback projections from the PCX and AON may be poised to impact odor perception, perhaps differentially.

The OT is an olfactory cortical structure situated within the ventral striatum (Alheid and Heimer, 1988; Wesson and Wilson, 2011). Previous work has described its roles in odor processing (Wesson and Wilson, 2010; Payton et al., 2012; Carlson et al., 2014, 2018; Xia et al., 2015), odor hedonics (Agustín-Pavón et al., 2014; FitzGerald et al., 2014; Gadziola et al., 2015; Murata et al., 2015; Howard et al., 2016; Zhang et al., 2017a), and motivated behavior (Prado-Alcala et al., 1984; Ikemoto, 2003; Sellings et al., 2006; Agustín-Pavón et al., 2014; FitzGerald

Correspondence should be addressed to Hillary L. Cansler at hillary.cansler@ufl.edu.

https://doi.org/10.1523/ENEURO.0390-18.2019

Copyright (C) 2019 in 't Zandt et al.

This is an open-access article distributed under the terms of the Creative Commons Attribution 4.0 International license, which permits unrestricted use, distribution and reproduction in any medium provided that the original work is properly attributed. et al., 2014; DiBenedictis et al., 2015; Gadziola and Wesson, 2016). The OT receives input from multiple olfactory structures, including the OB, AON, and PCX, as well as numerous brain regions important for affect, motivation, and cognition (White, 1965; Schwob and Price, 1984; Zahm and Heimer, 1987; Cleland and Linster, 2003; Ikemoto, 2007; Wesson and Wilson, 2011; Zhang et al., $2017 \mathrm{~b})$. OT targets include a similarly wide array of structures, with its principle output neurons being medium spiny neurons that innervate basal ganglia as well as additional structures (Wesson and Wilson, 2011; Zhang et al., 2017b). Notably, some studies have concluded, based on tracing methods or electrophysiological recordings, that the OT innervates the OB (Heimer, 1968; Shafa and Meisami, 1977; Gervais, 1979; Zhang et al., 2017b).

We set off with the goal to explore the organization, cell types, and functional role of these reported OT projections to the OB. To do so we employed tracing methods in non-transgenic mice and in a floxed reporter line. Ultimately, all the tracing methods we used failed to reveal OT projections to the OB, suggesting that the OT does not centrifugally contribute to early olfactory processing, in contrast with previous reports.

\section{Materials and Methods}

\section{Animals}

Three different experimental approaches were used (Fig. 1). Two used C57BL/6J mice (bred in University of Florida vivarium from breeder stock originating from The Jackson Laboratory), and one used Cre-dependent reporter mice Gt(ROSA)26Sor ${ }^{\text {tm9(CAG-tdTomato)Hze }}$ (Madisen et al., 2012) obtained from Jackson Labs ("Ai9"; stock \#007905, The Jackson Laboratory). First, C57BL/6J mice received unilateral OB injections of red retrobeads (Lumafluor, Inc.) following surgical procedures described below and were perfused $2 \mathrm{~d}$ later (Fig. 1A). Second, C57BL/6J mice received unilateral $\mathrm{OB}$ injections of the adenoassociated virus (AAV) pAAV-hSyn-EGFP ("AAVretroGFP"; Addgene viral prep \#50465-AAVrg) and were perfused two weeks later (Fig. 1B). Additional mice received OT injections of AAVretro-GFP to confirm that the virus used was capable of infecting OT neurons and were perfused one week later. Finally, homozygous Ai9 mice received unilateral OB injections of pAAV-Ef1 $\alpha$-mCherryIRES-Cre ("AAVretro-Cre"; Addgene viral prep \#55632$A A V r g$ ) and were perfused two weeks later (Fig. 1C). Again, additional Ai9 mice received OT injections of AAVretro-Cre to confirm that the virus used was capable of infecting OT neurons and were perfused one week later.

All mice were 6-12 weeks old ( $n=19$ male, $n=4$ female). All animal procedures were in accordance with the guidelines of the National Institutes of Health and were approved by the Institutional Animal Care and Use Committee at the University of Florida. Mice were housed in groups on a 12/12 h light/dark cycle with ad libitum access to food and water. 
A

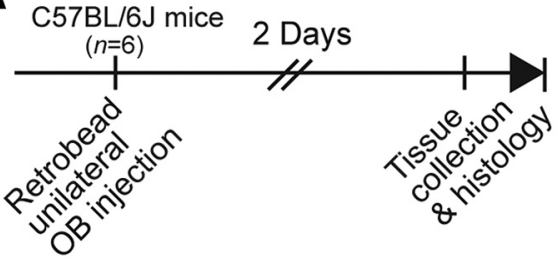

B
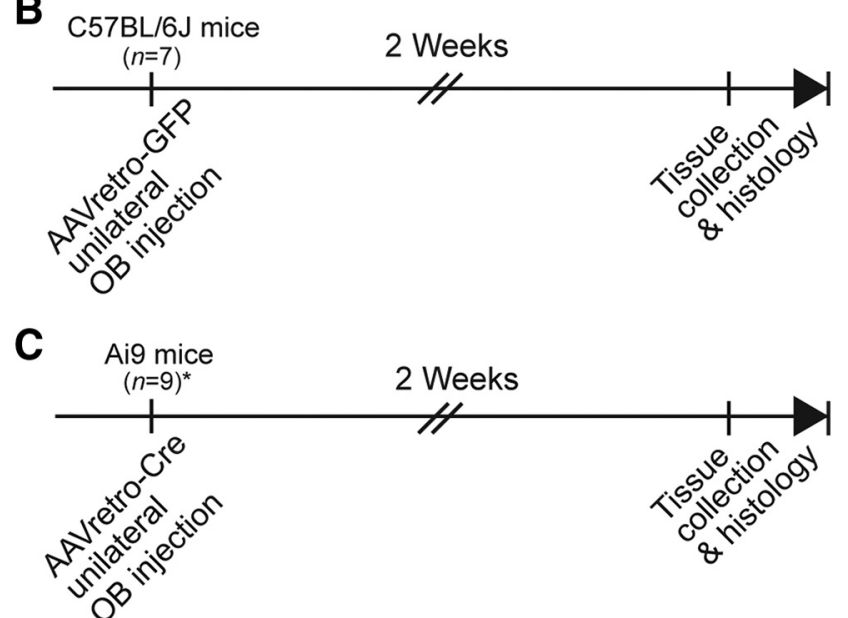

Figure 1. Timeline of methods and experimental groups. Three groups of mice were used in three different experimental paradigms. $\boldsymbol{A}, \mathrm{C} 57 \mathrm{BL} / 6 \mathrm{~J}$ mice received retrobead injections into the $\mathrm{OB}$ and were perfused at $2 \mathrm{~d}$. B, C57BL/6J mice received AAVretro-GFP injections into the $\mathrm{OB}$ and were perfused at two weeks. $\boldsymbol{C}$, Transgenic Ai9 reporter mice received AAVretro-Cre injections and were perfused at two weeks; *three of nine Ai9 mice received multiple injections of AAVretro-Cre throughout one OB (see Materials and Methods; Table 1).

\section{Surgical procedures}

Mice were anesthetized with $\sim 3 \%$ isoflurane in $1 \mathrm{l} / \mathrm{min}$ $\mathrm{O}_{2}$ and mounted into a stereotaxic frame, equipped with a heating pad to maintain body temperature at $38^{\circ} \mathrm{C}$. Depth of anesthesia was confirmed by lack of toe-pinch response and meloxicam analgesic was administered subcutaneously (5 mg/kg; Putney, Inc.). After removing fur, the scalp was cleaned using betadine followed by $70 \%$ ethanol. Subcutaneous marcaine $(1.7 \mathrm{mg} / \mathrm{kg}$; Hospira,
Inc.) was provided locally before midline incision. A craniotomy was made above the structure of interest, a glass micropipette containing retrobeads or AAV was lowered into the brain, and the injection was given at a rate of 2 $\mathrm{nl} / \mathrm{s}$ (see below for experiment-specific details). OB injections were given at $1.5 \mathrm{~mm}$ anterior to the rhinal sinus, 1 $\mathrm{mm}$ lateral, and $1.5 \mathrm{~mm}$ ventral unless noted otherwise (Table 1). All OT injections were given at $1.5 \mathrm{~mm}$ anterior bregma, $1.2 \mathrm{~mm}$ lateral, and $4.8 \mathrm{~mm}$ ventral. Following injection, the micropipette was slowly withdrawn from the brain, the craniotomy sealed with wax, and the wound closed with Vetbond (3M Animal Care Products). The mice were returned to group housing immediately following surgery and were allowed to recover on a heating pad.

All experiments are summarized in Table 1. A total of 6 C57BL/6J mice ( $n=5$ male, $n=1$ female) received unilateral injections of retrobeads in the OB. Each mouse received either $200 \mathrm{nl}$ of retrobeads $1500 \mu \mathrm{m}$ ventral to the surface $(n=2)$ or $900 \mathrm{nl}$ evenly dispersed between 2400 and $800 \mu \mathrm{m}$ ventral to the surface $(n=4)$. These differing strategies were employed to explore whether spatial targeting of the retrobeads in the OB impacted the outcome. We found that injecting 900 versus $200 \mathrm{nl}$ resulted in a similar number of labeled cells in the AON (56.9 \pm 12.8 vs $38.8 \pm 6$ cells; mean \pm SEM) and PCX (39.9 \pm 5.2 vs $34.7 \pm 5.1$ cells). A total of seven male C57BL/6J mice received 200-nl unilateral injections of AAVretroGFP in the OB. An additional two male C57BI/6J mice received a 500-nl injection of AAVretro-GFP in the OT. A total of six male Ai9 mice received 200 -nl unilateral injections of AAVretro-Cre in the $\mathrm{OB}$. Later, an additional three Ai9 mice (one male, two female) received three 200-nl OB injections each (at $1 \mathrm{~mm}, 1.5 \mathrm{~mm}$, and $2 \mathrm{~mm}$ anterior to the rhinal sinus, $1 \mathrm{~mm}$ lateral, and $1.5 \mathrm{~mm}$ ventral), for a total of 600-nl AAVretro-Cre per mouse. An additional two Ai9 mice (one male, one female) received $500-n l$ unilateral injections of AAVretro-Cre in the OT.

\section{Perfusion and histology}

All mice were overdosed with Fatal-plus $(0.01 \mathrm{ml} / \mathrm{g}$; Vortech Pharmaceutical, Ltd.) and perfused with $10 \mathrm{ml}$ of cold saline followed by $15 \mathrm{ml}$ of $10 \%$ PB formalin. Brains

Table 1. Summary of all injections

\begin{tabular}{|c|c|c|c|c|c|}
\hline Strain & $n$ & $\begin{array}{l}\text { Injected } \\
\text { with }\end{array}$ & $\begin{array}{l}\text { Injection } \\
\text { site }\end{array}$ & $\begin{array}{l}\text { Injection } \\
\text { amount }\end{array}$ & Figure \\
\hline C57BL/6J & $4(3 \mathrm{M}, 1 \mathrm{~F})$ & Retrobeads & $\begin{array}{l}\text { OB (dispersed } \\
\text { between } 2400 \\
\text { and } 800 \mu \mathrm{m} \text { ventral) }\end{array}$ & $900 \mathrm{nl}$ & $2 A-C, 3$ \\
\hline C57BL/6J & $2 \mathrm{M}$ & Retrobeads & $\mathrm{OB}$ & $200 \mathrm{nl}$ & $2 A-C, 3$ \\
\hline C57BL/6J & $7 \mathrm{M}$ & AAVretro-GFP & OB & $200 \mathrm{nl}$ & $2 D, 4 A-G$ \\
\hline C57BL/6J & $2 M$ & AAVretro-GFP & OT & $500 \mathrm{nl}$ & $4 H$ \\
\hline Ai9 & $6 \mathrm{M}$ & AAVretro-Cre & OB & $200 \mathrm{nl}$ & $2 E, 5 A-G$ \\
\hline Ai9 & $1 \mathrm{M}, 1 \mathrm{~F}$ & AAVretro-Cre & OT & $500 \mathrm{nl}$ & $5 H$ \\
\hline Ai9 & $1 \mathrm{M}, 2 \mathrm{sF}$ & AAVretro-Cre & $\begin{array}{l}\mathrm{OB}(1,1.5 \text {, and } 2 \mathrm{~mm} \text { anterior } \\
\text { the rhinal sinus, } 1 \mathrm{~mm} \\
\text { lateral, } 1.5 \mathrm{~mm} \text { ventral) }\end{array}$ & $\begin{array}{r}200 \mathrm{nl} \times 3 \text { sites } \\
=600 \mathrm{nl} \text { total }\end{array}$ & 6 \\
\hline
\end{tabular}

Unless otherwise noted, OB injections were given at $1.5 \mathrm{~mm}$ anterior the rhinal sinus, $1 \mathrm{~mm}$ lateral, and $1.5 \mathrm{~mm}$ ventral, and OT injections were given at 1.5 $\mathrm{mm}$ anterior bregma, $1.2 \mathrm{~mm}$ lateral, and $4.8 \mathrm{~mm}$ ventral. 
were stored in $10 \%$ formalin $/ 30 \%$ sucrose $\left(4^{\circ} \mathrm{C}\right)$ before sectioning.

All brains were frozen and alternate coronal sections were obtained with a sliding microtome at $40-\mu \mathrm{m}$ thickness and stored floating in TBS with $0.03 \%$ sodium azide. Sections containing the OB, AON, anterior PCX (aPCX), and/or OT were rinsed in deionized water and mounted on slides using Fluoromount-G containing 4',6-diamidino-2phenylindole (DAPI; Invitrogen). We selected 4-13 sections of each brain region for quantification, ensuring that sections spanned the anterior-posterior length of each region.

\section{Imaging}

Brain areas of interest (OB, AON, aPCX, OT) were identified based on the atlas of Paxinos and Franklin (Paxinos and Franklin, 2000) and images acquired of the hemisphere ipsilateral to the $\mathrm{OB}$ injection. Imaging was performed with a Nikon Eclipse Ti2e fluorescent microscope at $20 \times$ magnification using a Nikon 16MP DS-Qi2 monochrome CMOS camera. Images of the OT following injections of AAV locally within the OT were acquired at $40 \times$ magnification. Images of the intact brain were taken using a 12 MP digital camera, and for fluorescence a Nikon AZ100 microscope at $1 \times$ magnification using a Photometrics CoolSNAP DYNO CCD camera. Image acquisition settings, including gain, exposure, and light intensity, were held constant across all images and samples within treatment conditions.

\section{Quantification and statistics}

Successful injection was confirmed by observation of labeling in structures known to robustly innervate the $\mathrm{OB}$ (AON and aPCX; Price and Powell, 1970; Luskin and Price, 1983; Boyd et al., 2012; Markopoulos et al., 2012; Rothermel and Wachowiak, 2014; Padmanabhan et al., 2016). One out of seven AAVretro-GFP mice and two out of six AAVretro-Cre mice were excluded due to a lack of fluorescence anywhere in the brain, likely due to a mechanical failure of the injection.

An ROI bounding box $(500 \times 250 \mu \mathrm{m})$ was overlaid within each brain region of interest (aPCX, AON, OT), with effort made to hold the location of this bounding box constant across mice. Using semi-automated thresholding methods in NIS Elements (Nikon), we identified cells within these ROls, allowing for an unbiased estimation of cell numbers. This first involved preprocessing of the image to decrease background fluorescence and thereby enhance contrast. Then cells were identified based on their fluorescence intensity (via threshold) and their size. Lastly, detected objects were post-processed based on their area of fluorescence, resulting in the elimination of objects too small to be cells (e.g., brightly labeled fibers in the Ai9 paradigm). Due to overt differences in cell-filling across our three tracing paradigms, these methods were optimized for each method individually, but an identical method was used across all images within a paradigm. Representative results from the semi-automated cellcounting procedures for each experimental paradigm are shown in Figure 2.
For each region analyzed, multiple sections were quantified for each mouse, with some variation in the number of sections quantified for each mouse ( $n=16$ mice, 6.75 \pm 0.38 sections per brain region per mouse). This variation was due to occasional histologic imperfections (e.g., bubbles in the mounting medium or torn tissue) that precluded accurate quantification and resulted in the exclusion of some samples. To avoid overrepresenting mice for which more samples were analyzed, we calculated a mean for each region, and averaged these means across mice for each region. Any ROIs resulting in values exceeding two standard deviations outside the mean for that ROI were eliminated from all quantification and statistical analyses. This largely was applied toward retrobead-treated tissue wherein some sections had abundant fluorescence resulting from residual retrobeads collecting on the microtome blade and being deposited on latter sections.

\section{Results}

\section{Retrobead labeling suggests lack of OT to OB innervation}

In our first experimental paradigm (Fig. $1 A$ ), we injected retrobeads unilaterally in the OB of C57BL/6J mice (Fig. $3 A$ ). At the site of injection, retrobeads are endocytosed and retrogradely transported to the soma, resulting in an accumulation of retrobeads and fluorescently labeled soma. As expected, this resulted in fluorescent soma in the AON and aPCX, two structures known to innervate the OB (Price and Powell, 1970; Luskin and Price, 1983; Boyd et al., 2012; Markopoulos et al., 2012; Rothermel and Wachowiak, 2014; Padmanabhan et al., 2016; Fig. 3B-E). Unexpectedly, our automated cell counting returned only a few positive OT values, from just a subset of tissue sections (Fig. 3F,G). On visual inspection of the counted "cells" in the OT, and inspection of z-stack images, we determined that these were non-neuronal fluorescent puncta (Fig. 2B), likely residual retrobeads deposited on the tissue during sectioning.

\section{Viral tracing further supports lack of centrifugal OT to OB input}

Given the surprising lack of OT fluorescence observed in the retrobead experiment, we sought to confirm our findings by using a viral labeling technique (Fig. 1B) to rule out the possibility of a false negative result. We unilaterally injected C57BL/6J mice in the OB with AAVretro-GFP to label neurons projecting to the $\mathrm{OB}$ (Fig. $4 A$ ). This virus drives GFP expression under control of the human synapsin promoter, and is thus capable of labeling any neuronal cell type (Kügler et al., 2003), including medium spiny neurons of the ventral striatum (McLean et al., 2014) of which the OT is largely comprised. With this independent paradigm, we observed many GFP-labeled neurons in the AON and aPCX (Fig. $4 B-E$ ), indicating that we were successful in labeling neurons that centrifugally innervate the OB. In contrast, we again observed a lack of fluorescent neurons in the OT (Fig. $4 B-G$ ).

To ensure that the virus we used is capable of infecting and driving GFP expression in OT neurons, we unilaterally injected the OT directly with AAVretro-GFP in a separate 


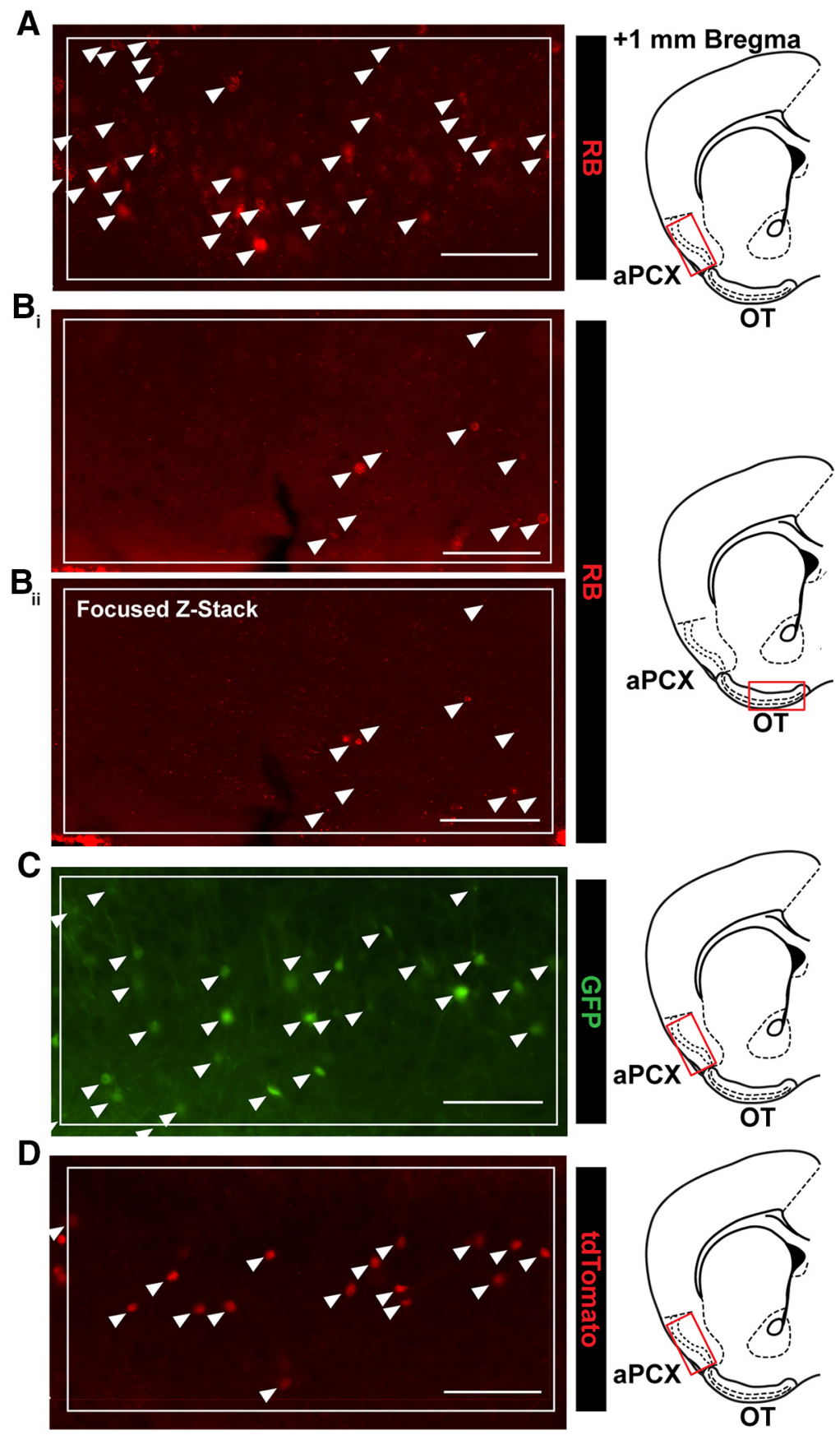

Figure 2. Representative results from semi-automated cell-counting procedures. $\boldsymbol{A}$, Representative results from semi-automated quantification of retrobead-labeled cells in aPCX. RB, retrobead. $\boldsymbol{B}_{i}$, Representative results from semi-automated quantification of retrobead-labeled cells in the OT. $\boldsymbol{B}_{i i}$, Same section as shown in $\boldsymbol{B}_{\boldsymbol{i}}$, as a focused z-stack, indicating that many cells counted were likely non-neuronal fluorescent puncta. Z-stack included six steps, with $4 \mu \mathrm{m}$ between each step. $\boldsymbol{C}$, Representative results from semi-automated quantification of GFP-labeled cells in the aPCX following injection of AAVretro-GFP in the OB. $\boldsymbol{D}$, Representative results from semi-automated quantification of tdTomato-labeled cells in the aPCX following injection of AAVretro-Cre in the OB. Arrows indicate counted cells. Boxed region indicates ROI used for quantification. All scale bars $=100$ $\mu \mathrm{m}$.

cohort of C57BL/6J mice. We observed GFP expression in OT neurons across all cell layers of the OT (Fig. 4H), including in the islands of Calleja, suggesting that the lack of GFP expression in the OT following AAVretro-GFP injection into the $\mathrm{OB}$ is not due to an issue of $A A V$ tropism for OT neurons.

\section{Cre-dependent labeling strategy confirms lack of OT to OB pathway}

Finally, we employed a third strategy in an attempt to label this pathway. We used Ai9 reporter mice, which robustly express tdTomato in a Cre-dependent manner (Madisen et al., 2010). We unilaterally injected AAVretro- 


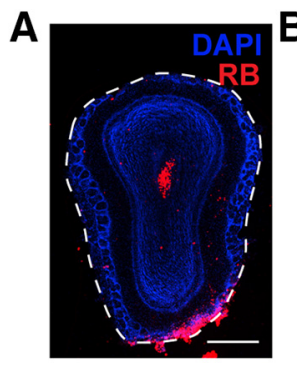

D

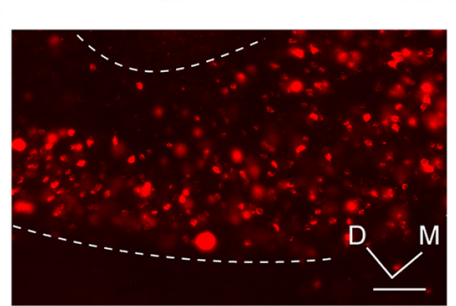

$\mathbf{F}$

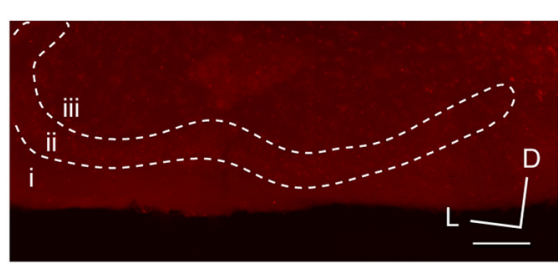

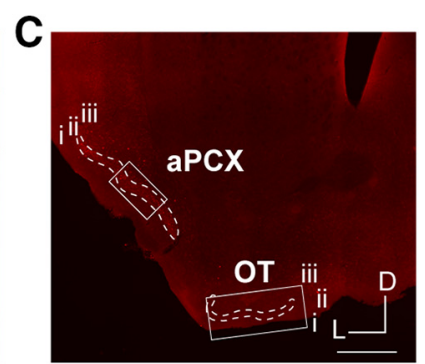

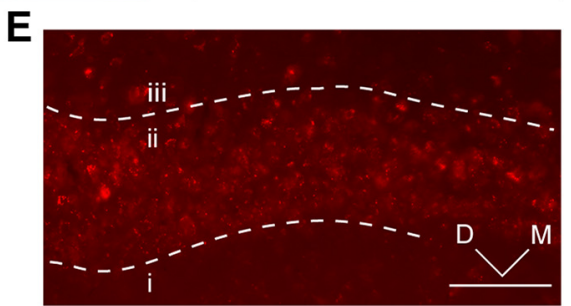

G

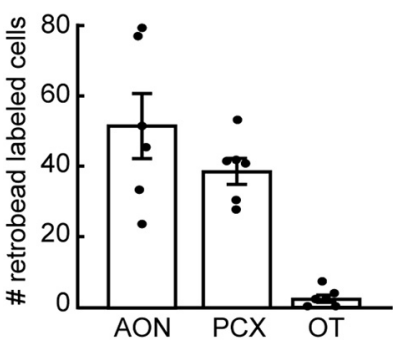

Figure 3. Retrobead injections to the OB indicate lack of OT to OB innervation. $\boldsymbol{A}$, OB injection site. Dotted line indicates the glomerular layer. Scale bar $=500 \mu \mathrm{m}$. $\boldsymbol{B}$, Retrobead labeling in the AON following OB injection. Box indicates region in $\boldsymbol{D}$. Scale bar $=200 \mu \mathrm{m}$. $\boldsymbol{C}$, aPCX and OT retrobead labeling. Boxes indicate regions in $\boldsymbol{E}, \boldsymbol{F}$. Scale bar $=500 \mu \mathrm{m}$. $\boldsymbol{D}$, Enhanced view of boxed AON region in $\boldsymbol{B}$. Scale bar $=100 \mu \mathrm{m}$. $\boldsymbol{E}$, Enhanced view of boxed aPCX region in $\boldsymbol{C}$. Scale bar $=100 \mu \mathrm{m}$. $\boldsymbol{F}$, Enhanced view of boxed OT region in C. Scale bar $=100 \mu \mathrm{m}$. G, Estimated number of retrobead-labeled cells across all three brain regions. Each point represents one animal's mean; $n=6$ mice, four to six sections (4.78 \pm 0.19 ; mean \pm SEM) each. i.-iii., layers 1-3; D, dorsal; M, medial; L, lateral.

Cre (which drives Cre expression under control of the Ef $1 \alpha$ promoter and is thus capable of driving Cre expression in any mammalian cell) into the $\mathrm{OB}$ (Figs. 1C, 5A). This strategy resulted in robust tdTomato expression in structures known to innervate the $\mathrm{OB}$, including the $\mathrm{APCX}$ and AON (Fig. $5 B-E$ ). We observed a complete and striking lack of cells in the OT (Fig. 5F), which was in stark contrast to the plentiful cells observed in the AON and the aPCX (Fig. 5G).

Once again, to ensure that the virus we used is capable of infecting OT neurons, we injected AAVretro-Cre directly into the OT of a separate cohort of Ai9 mice. As for AAVretro-GFP (Fig. 4H), this approach yielded fluorophore-expressing cells throughout the OT (Fig. 5H).

Finally, we wanted to ensure that we were not inadvertently missing any regions of the $\mathrm{OB}$ that may be the target of OT centrifugal input. Indeed, it is possible OT projections to the $\mathrm{OB}$ may innervate notably small portions of the $\mathrm{OB}$, which might be missed with the single bolus injections largely employed in the previous approaches (although those injections often did span OB cell layers (Figs. $4 A, 5 A$ ). We also sought to ensure our retrograde $\mathrm{OB}$ injection approaches were capable of labeling neurons in structures other than just the aPCX and AON. To accomplish these goals, we unilaterally injected an additional cohort of Ai9 mice with AAVretro-Cre at three sites along the anterior-posterior axis in the same $\mathrm{OB}$ and collected tissue sections throughout the entire brain (in contrast to the previous paradigms wherein we only collected forebrain tissue and analyzed the aPCX, $\mathrm{AON}$, and OT). This strategy resulted in robust tdTomato expression throughout the entire OB (Fig. 6A), which was evident even on looking at the intact brain (Fig. 6B). tdTomato expression appeared absent within the OT when viewing the ventral side of the intact brain with the naked eye and under epifluorescence (Fig. 6B). After sectioning, we again did not observe fluorescent neurons in the OT (Fig. 6C), in contrast to significant labeling in many other structures known to innervate the $\mathrm{OB}$, including the aPCX (Fig. 6C), dorsal tenia tecta (Shipley and Adamek, 1984; Fig. 6C), AON (Fig. 6D), horizontal diagonal band of Broca (Ichikawa and Hirata, 1986; Devore and Linster, 2012; Rothermel et al., 2014; Fig. 6E), magnocellular preoptic area (Carson, 1984; Fig. 6E), posterior PCX (Fig. 6F), lateral hypothalamus (Shipley and Adamek, 1984; Fig. $6 G$ ), basolateral amygdala (Fig. $6 H$ ), median and dorsal raphe nuclei (Steinfeld et al., 2015; Brunert et al., 2016; Fig. 6/,J), and locus coeruleus (Shipley et al., 1985; McLean et al., 1989; Fig. 6K). Because this approach resulted in very thorough labeling of the $\mathrm{OB}$, as well as 

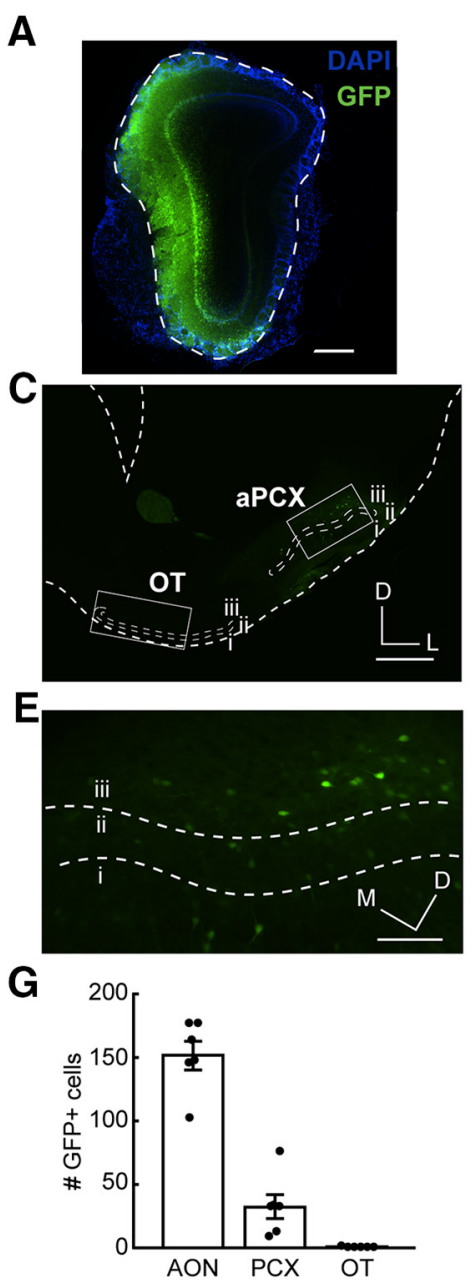

$\mathbf{B}$
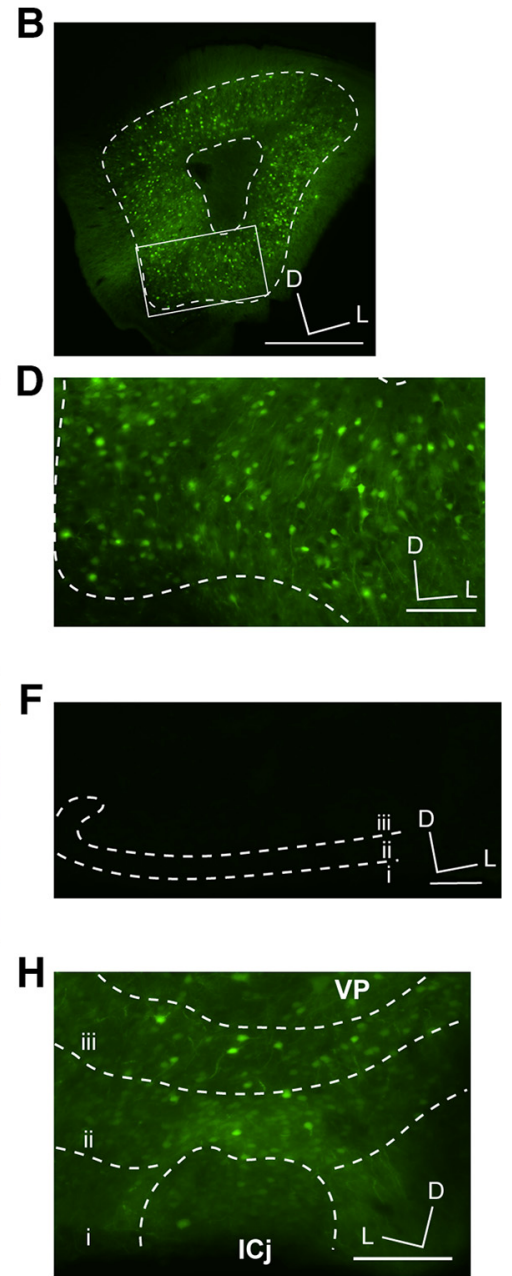

Figure 4. AAVretro-GFP tracing further supports lack of OT to OB innervation. $\boldsymbol{A}, \mathrm{OB}$ injection site. Dotted line indicates the glomerular layer. Scale bar $=500 \mu \mathrm{m}$. B, AON GFP labeling following injection of AAVretro-GFP in the OB. Box indicates region in Figure 3D. Scale bar $=500 \mu \mathrm{m}$. C, aPCX and OT GFP labeling following injection of AAVretro-GFP in the OB. Boxes indicate regions in Figure $3 E, F$. Scale bar $=500 \mu \mathrm{m}$. $\boldsymbol{D}$, Enhanced view of boxed AON region in B. Scale bar $=100 \mu \mathrm{m}$. $\boldsymbol{E}$, Enhanced view of boxed aPCX region in $\boldsymbol{C}$. Scale bar $=100 \mu \mathrm{m}$. $\boldsymbol{F}$, Enhanced view of boxed OT region in $\boldsymbol{C}$. Scale bar $=100 \mu \mathrm{m}$. G, Quantification of GFP-labeled cells across all three brain regions. Each point represents one animal's mean; $n=6$ mice, $4-12$ sections $(6.89 \pm 0.54$; mean $\pm \mathrm{SEM})$ each. $\boldsymbol{H}$, GFP labeling in the OT following injection of AAVretro-GFP in the OT; $n=2$ mice. VP, ventral pallidum; ICj, islands of Calleja; ICj, borders were approximated based on DAPI staining. Scale bar = $100 \mu \mathrm{m}$. i.-iii., layers 1-3; D, dorsal; M, medial; L, lateral.

labeling in many areas known to innervate the OB, these results provide strong evidence that the OT does not send centrifugal projections to the OB (Fig. 7). Together with our results from 16 mice across three different quantitative experimental approaches (six retrobead, six AAVretro-GFP, and four AAVretro-Cre; Figs. 3-6), we observed no OB-projecting OT neurons, providing strong support for our conclusion that the OT does not project to the OB.

\section{Discussion}

Here, we demonstrate a lack of input from the OT to the $\mathrm{OB}$. While we initiated this study with the goal of investigating the anatomic organization and physiologic role of this reported pathway (Shafa and Meisami, 1977), our results ultimately lead us to the conclusion that it does not exist. To minimize the chance of a false negative result, we used three independent, widely-used tracing meth- ods, each of which yielded congruent results. Our use of a retrograde labeling strategy eliminated the possibility that we may have introduced non-specific labeling due to off-target effects that can accompany anterograde tracing methods when the structure of interest is difficult to target due to small size or irregular shape, like the OT. The regions of interest were chosen in the same portion of the structures across all animals within each experiment to ensure fair sampling. Further, we set rigorous standards for sample exclusion, excluding only samples that showed no labeling in regions with very wellcharacterized, dense projections to the OB.

In only one of our experimental paradigms, the retrobead paradigm, did our semi-automated cell counting return positive cell counts in the OT. For some of these instances, we performed z-stack imaging which indicated that the cells counted were actually non-neuronal fluores- 


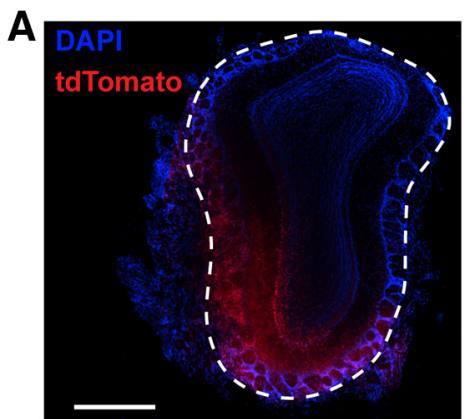

C

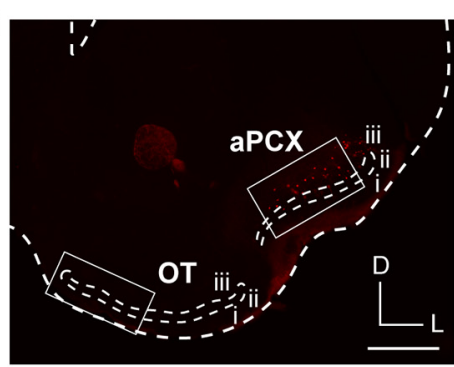

E

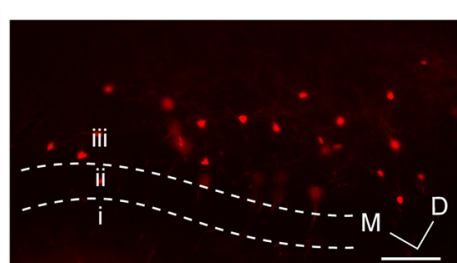

G

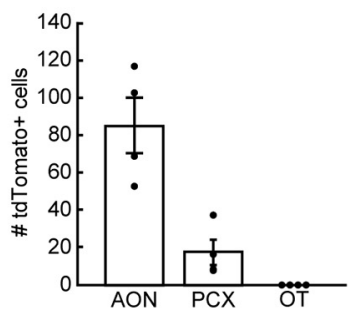

B
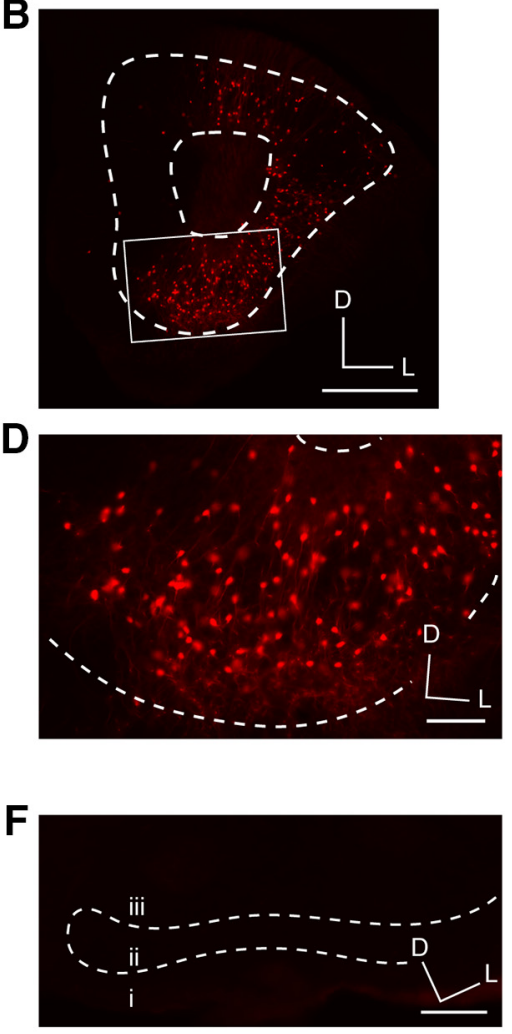

$\mathrm{H}$

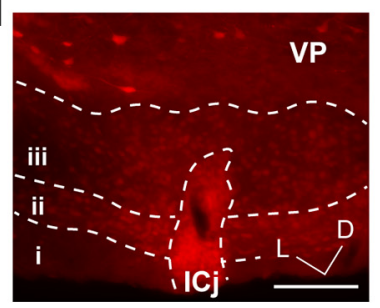

Figure 5. AAVretro-Cre tracing in Ai9 reporter mouse verifies lack of OT to OB innervation. $\boldsymbol{A}, \mathrm{OB}$ injection site. Dotted line indicates the glomerular layer. Scale bar $=500 \mu \mathrm{m}$. B, AON tdTomato labeling following injection of AAVretro-Cre in the OB of Ai9 mouse. Box indicates region in Figure $4 D$. Scale bar $=500 \mu \mathrm{m}$. C, aPCX and OT tdTomato labeling following injection of AAVretro-Cre in the OB of Ai9 mouse. Boxes indicate regions in Figure $4 E, F$. Scale bar $=500 \mu \mathrm{m}$. $\boldsymbol{D}$, Enhanced view of boxed AON region in $\boldsymbol{B}$. Scale bar $=100 \mu \mathrm{m}$. $\boldsymbol{E}$, Enhanced view of boxed aPCX region in $\boldsymbol{B}$. Scale bar $=100 \mu \mathrm{m}$. $\boldsymbol{F}$, Enhanced view of boxed OT region in $\boldsymbol{C}$. Scale bar $=100 \mu \mathrm{m}$. G, Quantification of tdTomato-labeled cells across all the three brain regions. Each point represents one animal's mean; $n=4$ mice, $5-13$ sections/mouse $(9.5 \pm 0.68$; mean \pm SEM). $\boldsymbol{H}$, OT neurons labeled following injection of AAVretro-Cre in the OT of Ai9 mouse; $n=2$ mice. VP, ventral pallidum; ICj, islands of Calleja. ICj borders were approximated based on DAPI staining. Scale bar = $100 \mu \mathrm{m}$. i.-iii., layers 1-3; D, dorsal; M, medial; L, lateral.

cent puncta. It seems those artifacts were residual retrobeads that were deposited by the microtome blade onto subsequent sections (an issue we observed and noted during the tissue sectioning). This issue may also contribute to the fact that we counted slightly more cells in the aPCX in the retrobead experiments compared to the AAV experiments. In support of OT cells not innervating the $\mathrm{OB}$, the results we obtained using the two viral tracing techniques indicated a complete absence of cells in the OT.

We did observe some slight differences in the numbers of cells labeled by each tracing method. For example, we observed slightly more retrobead-labeled neurons in the aPCX compared to either viral tracing method, which were likely due to differences in the efficiency of endocytosis and transport of the retrobeads compared to virallymediated GFP or Cre expression. Importantly, each method indicated the same pattern of labeling, with the densest labeling in the AON, followed by the APCX, and no labeling in the OT. Overall, the slight differences we observed with each technique highlight the importance of using multiple strategies in our attempt to identify OBprojecting OT neurons.

The failure of all three of our primary strategies to label OT neurons projecting to the OB provides strong support for our conclusion that this population does not exist. This is further strengthened by the outcomes of our follow-up experiments, wherein we injected multiple boluses of 
A

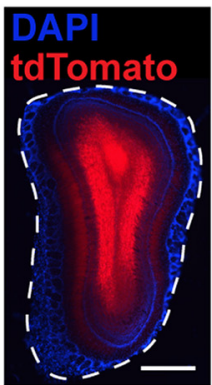

B

C

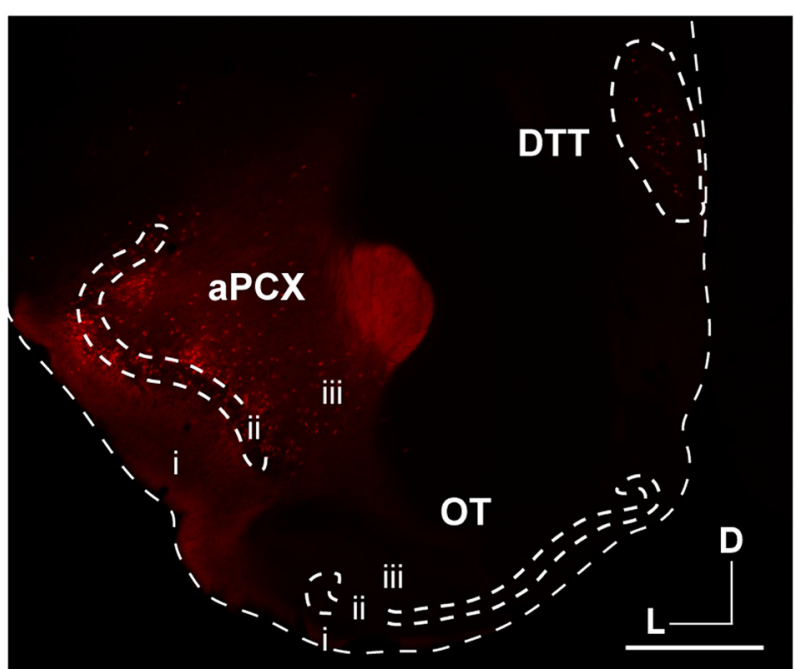

F

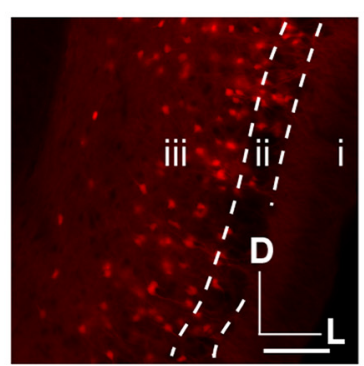

I

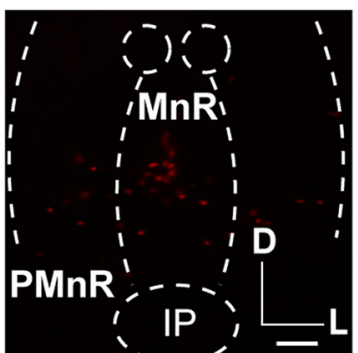

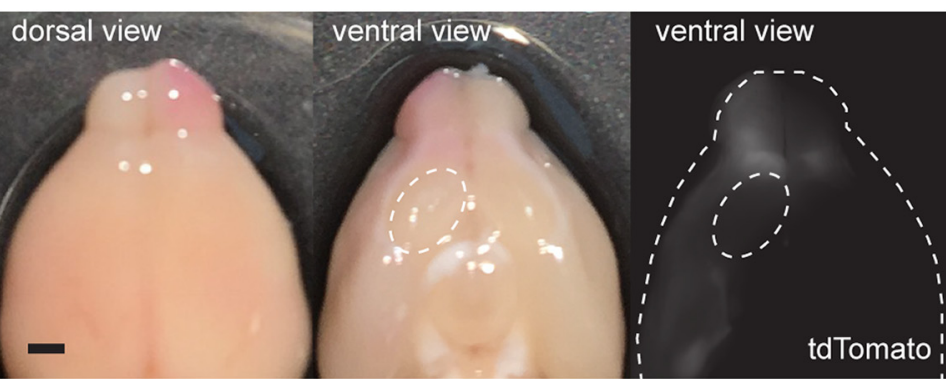

D

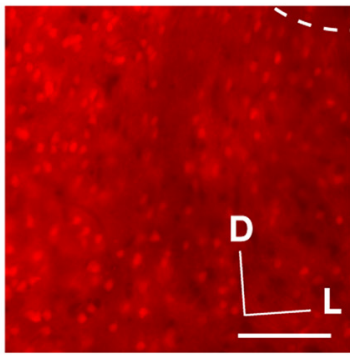

E

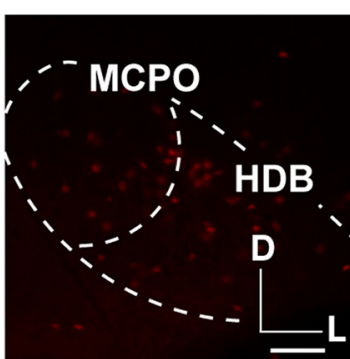

H

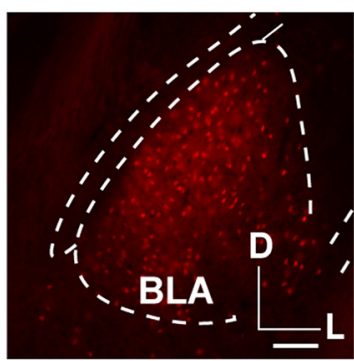

K

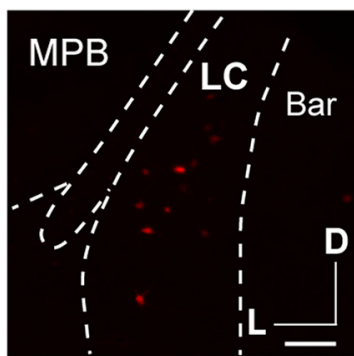

Figure 6. Multiple injections of AAVretro-Cre in the OB of Ai9 reporter mouse reveals labeling in numerous OB-projecting structures, but not the OT. $\boldsymbol{A}$, OB injection site. Dotted line indicates the glomerular layer. Scale bar $=500 \mu \mathrm{m}$. $\boldsymbol{B}$, Intact brain following multiple injections of AAVretro-Cre in the OB of Ai9 reporter mouse shows strong tdTomato labeling in one OB and the PCX, but not the OT. Dotted line indicates the OT. Scale bar $=1 \mathrm{~mm}$. $\boldsymbol{C}$, aPCX and OT tdTomato labeling following injection of AAVretro-Cre in the OB of Ai9 mouse. Scale bar $=500 \mu \mathrm{m}$. $\boldsymbol{D}-\boldsymbol{K}$, tdTomato labeling in many regions following injection of AAVretro-Cre in the OB of Ai9 mouse. All scale bars $=100 \mu \mathrm{m}$. $\boldsymbol{D}$, AON. E, Horizontal diagonal band of Broca (HDB) and magnocellular preoptic nucleus (MCPO). $\boldsymbol{F}$, Posterior PCX (pPCX). G, Lateral hypothalamus (LH). $\boldsymbol{H}$, Basolateral amygdala (BLA). $\boldsymbol{I}$, Median raphe nucleus (MnR) and paramedian raphe nucleus (PMnR). J, Dorsal raphe nucleus (DR). $\boldsymbol{K}$, Locus coeruleus (LC). f, fornix; ns, nigrostriatal bundle; IP, interpeduncular nucleus; VLPAG, ventrolateral periaqueductal gray; Su3, supraoculomotor cap; MPB, medial parabrachial nucleus; Bar, Barrington's nucleus. i.-iii., layers $1-3$; $\mathrm{D}$, dorsal; $\mathrm{M}$, medial; L, lateral; $n=3$ mice. 


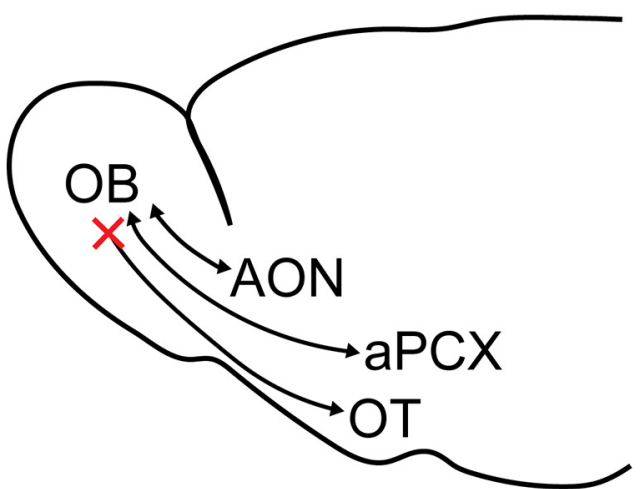

Figure 7. Revised model for centrifugal inputs to the $O B$. The $A O N$, aPCX, and OT receive input from the OB. The AON and aPCX send centrifugal input back to the $O B$, but based on our data, the OT does not.

AAVretro-Cre widely throughout the OB of Ai9 mice. This revealed, as expected, tdTomato expression in nearly one dozen brain structures with known innervation of the OB, but not the OT (Fig. 6).

Our results are surprising, given the previous reports that suggested the existence of this pathway. In one study (Shafa and Meisami, 1977), the authors injected HRP into the rat $\mathrm{OB}$. The authors concluded that there was some "light" labeling in the OT but did not provide quantitative analysis, and only presented minimal primary data. Two studies (Heimer, 1968; Gervais, 1979) revealed degeneration in the OB following lesions to the OT, suggesting that the OT sends feedback to the OB. The Heimer study (Heimer, 1968) mentions the difficulty of lesioning the OT without damaging neighboring structures, suggesting offtarget effects (namely, damage beyond the OT) may contribute to their result. The lesioning strategy used in the Gervais paper (Gervais, 1979) is subject to the same caveat. Indeed, some of their OT lesions resulted in damage to part of the lateral olfactory tract (which provides input to all olfactory cortices), thus introducing the possibility of highly non-specific effects. In both cases, even if lesions were perfectly confined to the OT, OB degeneration could result from the loss of an indirect connection to the $\mathrm{OB}$ via a third structure, rather than the loss of a monosynaptic connection.

A more recent study (Zhang et al., 2017b) used viral anterograde and retrograde tracing techniques to study the inputs and outputs of the OT. With an anterograde AAV injection into the OT, the authors reported labeling throughout the $\mathrm{OB}$, with the majority of fluorescence localized within the glomerular layer of the OB. As with the lesioning experiments discussed above, it can be quite difficult to exclusively target an injection to the mouse OT without any leak into surrounding areas (like the aPCX which does project to the $\mathrm{OB}$ ). Here, we avoid this caveat by using three independent retrograde labeling strategies, each of which indicates a lack of projection from the OT to the OB.

It is well established, and further supported by our data, that the $A O N$ and $P C X$ provide centrifugal innervation to the OB (Price and Powell, 1970; Luskin and Price, 1983;
Boyd et al., 2012; Markopoulos et al., 2012; Rothermel and Wachowiak, 2014; Padmanabhan et al., 2016). However, our results indicate a lack of direct input from the OT to the OB. What might this indicate about the role of the OT within the olfactory system? OT neurons receive input from the $\mathrm{OB}$ and encode odors in a cortical-like manner, suggesting a role in odor processing (Wesson and Wilson, 2010). Further, these responses are modulated by attention (Zelano et al., 2005; Carlson et al., 2018), and it has previously been speculated that the OT may play a role in top-down, state-dependent modulation of $\mathrm{OB}$ activity (Gervais, 1979; Wesson and Wilson, 2011). Ultimately, our data lead us to conclude that it is very unlikely the OT directly modulates OB activity, suggesting that statedependent modulation of $\mathrm{OB}$ activity must result from other sources of input (e.g., AON, aPCX), or indirect input from the OT by means of other structures. Of course, our data do not rule out the highly likely possibility that the OT may indirectly, via di- or even tri-synaptic connections, influence $\mathrm{OB}$ activity through its projections to regions that do innervate the $\mathrm{OB}$, like the aPCX or even AON. Future work could attempt to address this possibility using optogenetic and electrophysiological methods.

\section{References}

Ache BW, Young JM (2005) Olfaction: diverse species, conserved principles. Neuron 48:417-430. CrossRef Medline

Agustín-Pavón C, Martínez-García F, Lanuza E (2014) Focal lesions within the ventral striato-pallidum abolish attraction for male chemosignals in female mice. Behav Brain Res 259:292-296. CrossRef Medline

Alheid GF, Heimer L (1988) New perspectives in basal forebrain organization of special relevance for neuropsychiatric disorders: the striatopallidal, amygdaloid, and corticopetal components of substantia innominata. Neuroscience 27:1-39. Medline

Bajo VM, Nodal FR, Moore DR, King AJ (2010) The descending corticocollicular pathway mediates learning-induced auditory plasticity. Nat Neurosci 13:253-260. CrossRef Medline

Boyd AM, Sturgill JF, Poo C, Isaacson JS (2012) Cortical feedback control of olfactory bulb circuits. Neuron 76:1161-1174. CrossRef Medline

Brunert D, Tsuno Y, Rothermel M, Shipley MT, Wachowiak M (2016) Cell-type-specific modulation of sensory responses in olfactory bulb circuits by serotonergic projections from the raphe nuclei. $J$ Neurosci 36:6820-6835. CrossRef Medline

Brunjes PC, Illig KR, Meyer EA (2005) A field guide to the anterior olfactory nucleus (cortex). Brain Res Brain Res Rev 50:305-335. CrossRef Medline

Carlson KS, Dillione M, Wesson DW (2014) Odor- and statedependent olfactory tubercle local field potential dynamics in awake rats. J Neurophysiol 111:2109-2123. CrossRef Medline

Carlson KS, Gadziola MA, Dauster ES, Wesson DW (2018) Selective attention controls olfactory decisions and the neural encoding of odors. Curr Biol 28:2195-2205.e4. CrossRef Medline

Carson KA (1984) Quantitative localization of neurons projecting to the mouse main olfactory bulb. Brain Res Bull 12:629-634. CrossRef Medline

Cleland TA, Linster C (2003) Central olfactory structures. In: Handbook of olfaction and gustation (Doty RL, ed), pp 165-180. New York: Marcel Dekker.

Devore S, Linster C (2012) Noradrenergic and cholinergic modulation of olfactory bulb sensory processing. Front Behav Neurosci 6:52. CrossRef Medline

DiBenedictis BT, Olugbemi AO, Baum MJ, Cherry JA (2015) DREADD-induced silencing of the medial olfactory tubercle dis- 
rupts the preference of female mice for opposite-sex chemosignals. eNeuro 2. CrossRef Medline

FitzGerald BJ, Richardson K, Wesson DW (2014) Olfactory tubercle stimulation alters odor preference behavior and recruits forebrain reward and motivational centers. Front Behav Neurosci 8. CrossRef Medline

Fletcher ML, Chen WR (2010) Neural correlates of olfactory learning: critical role of centrifugal neuromodulation. Learn Mem 17:561570. CrossRef Medline

Gadziola MA, Wesson DW (2016) The neural representation of goaldirected actions and outcomes in the ventral striatum's olfactory tubercle. J Neurosci 36:548-560. CrossRef Medline

Gadziola MA, Tylicki KA, Christian DL, Wesson DW (2015) The olfactory tubercle encodes odor valence in behaving mice. J Neurosci 35:4515-4527. CrossRef Medline

Gervais G (1979) Unilateral lesions of the olfactory tubercle modifying general arousal effects in the rat olfactory bulb. Electroencephalogr Clin Neurophysiol 46:665-674. CrossRef

Gervais R, Pager J (1979) Combined modulating effects of the general arousal and the specific hunger arousal on the olfactory bulb responses in the rat. Electroencephalogr Clin Neurophysiol 46:87-94. Medline

Gilbert CD, Li W (2013) Top-down influences on visual processing. Nat Rev Neurosci 14:350-363. CrossRef Medline

Gottfried JA (2010) Central mechanisms of odour object perception. Nat Rev Neurosci 11:628-641. CrossRef Medline

Haberly LB (2001) Parallel-distributed processing in olfactory cortex: new insights from morphological and physiological analysis of neuronal circuitry. Chem Senses 26:551-576. Medline

Heimer L (1968) Synaptic distribution of centripetal and centrifugal nerve fibres in the olfactory system in the rat. J Anat 103:413-432. Medline

Howard JD, Kahnt T, Gottfried JA (2016) Converging prefrontal pathways support associative and perceptual features of conditioned stimuli. Nat Commun 7:11546. CrossRef Medline

Ichikawa T, Hirata Y (1986) Organization of choline acetyltransferasecontaining structures in the forebrain of the rat. J Neurosci 6:281292. CrossRef

Ikemoto S (2003) Involvement of the olfactory tubercle in cocaine reward: intracranial self-administration studies. J Neurosci 23: 9305-9311. Medline

Ikemoto S (2007) Dopamine reward circuitry: two projection systems from the ventral midbrain to the nucleus accumbens-olfactory tubercle complex. Brain Res Rev 56:27-78. CrossRef Medline

Kato HK, Chu MW, Isaacson JS, Komiyama T (2012) Dynamic sensory representations in the olfactory bulb: modulation by wakefulness and experience. Neuron 76:962-975. CrossRef Medline

Kiselycznyk CL, Zhang S, Linster C (2006) Role of centrifugal projections to the olfactory bulb in olfactory processing. Learn Mem 13:575-579. CrossRef Medline

Kügler S, Kilic E, Bähr M (2003) Human synapsin 1 gene promoter confers highly neuron-specific long-term transgene expression from an adenoviral vector in the adult rat brain depending on the transduced area. Gene Ther 10:337-347. CrossRef Medline

Lavin A, Alcocer-Cuaron C, Hernández-Peón R (1959) Centrifugal arousal in the olfactory bulb. Science 129:332-333. CrossRef

Luskin MB, Price JL (1983) The laminar distribution of intracortical fibers originating in the olfactory cortex of the rat. J Comp Neurol 216:292-302. CrossRef

Madisen L, Zwingman TA, Sunkin SM, Oh SW, Zariwala HA, Gu H, $\mathrm{Ng}$ LL, Palmiter RD, Hawrylycz MJ, Jones AR, Lein ES, Zeng $\mathrm{H}$ (2010) A robust and high-throughput Cre reporting and characterization system for the whole mouse brain. Nat Neurosci 13:133140. CrossRef Medline

Madisen L, Mao T, Koch H, Zhuo JM, Berenyi A, Fujisawa S, Hsu YW, Garcia AJ 3rd, Gu X, Zanella S, Kidney J, Gu H, Mao Y, Hooks BM, Boyden ES, Buzsáki G, Ramirez JM, Jones AR, Svoboda K, Han X, et al. (2012) A toolbox of Cre-dependent optogenetic transgenic mice for light-induced activation and silencing. Nat Neurosci 15:793-802. CrossRef Medline
Markopoulos F, Rokni D, Gire DH, Murthy VN (2012) Functional properties of cortical feedback projections to the olfactory bulb. Neuron 76:1175-1188. CrossRef Medline

McLean JH, Shipley MT, Nickell WT, Aston-Jones G, Reyher CK (1989) Chemoanatomical organization of the noradrenergic input from locus coeruleus to the olfactory bulb of the adult rat. J Comp Neurol 285:339-349. CrossRef

McLean JR, Smith GA, Rocha EM, Hayes MA, Beagan JA, Hallett PJ, Isacson O (2014) Widespread neuron-specific transgene expression in brain and spinal cord following synapsin promoter-driven AAV9 neonatal intracerebroventricular injection. Neurosci Lett 576: 73-78. CrossRef Medline

Murata K, Kanno M, leki N, Mori K, Yamaguchi M (2015) Mapping of learned odor-induced motivated behaviors in the mouse olfactory tubercle. J Neurosci 35:10581-10599. CrossRef Medline

Ogg MC, Ross JM, Bendahmane M, Fletcher ML (2018) Olfactory bulb acetylcholine release dishabituates odor responses and reinstates odor investigation. Nat Commun 9:1868. CrossRef Medline

Otazu GH, Chae H, Davis MB, Albeanu DF (2015) Cortical feedback decorrelates olfactory bulb output in awake mice. Neuron 86: 1461-1477. CrossRef Medline

Padmanabhan K, Osakada F, Tarabrina A, Kizer E, Callaway EM, Gage FH, Sejnowski TJ (2016) Diverse representations of olfactory information in centrifugal feedback projections. J Neurosci 36: 7535-7545. CrossRef

Paxinos G, Franklin K (2000) The mouse brain in stereotaxic coordinates, Ed 2. San Diego: Academic Press.

Payton CA, Wilson DA, Wesson DW (2012) Parallel odor processing by two anatomically distinct olfactory bulb target structures. PLoS One 7:e34926. CrossRef Medline

Petzold GC, Hagiwara A, Murthy VN (2009) Serotonergic modulation of odor input to the mammalian olfactory bulb. Nat Neurosci 12:784-791. CrossRef Medline

Prado-Alcala R, Streather A, Wise RA (1984) Brain stimulation reward and dopamine terminal fields. II. Septal and cortical projections. Brain Res 301:209-219. Medline

Price JL, Powell TP (1970) An experimental study of the origin and the course of the centrifugal fibres to the olfactory bulb in the rat. J Anat 107:215-237. Medline

Ross JM, Fletcher ML (2018) Learning-dependent and -independent enhancement of mitral/tufted cell glomerular odor responses following olfactory fear conditioning in awake mice. J Neurosci 38: 4623-4640. CrossRef

Rothermel M, Wachowiak M (2014) Functional imaging of cortical feedback projections to the olfactory bulb. Front Neural Circuits 8 . CrossRef Medline

Rothermel M, Carey RM, Puche A, Shipley MT, Wachowiak M (2014) Cholinergic inputs from basal forebrain add an excitatory bias to odor coding in the olfactory bulb. J Neurosci 34:4654-4664. CrossRef Medline

Schoppa NE, Urban NN (2003) Dendritic processing within olfactory bulb circuits. Trends Neurosci 26:501-506. CrossRef Medline

Schwob JE, Price JL (1984) The development of axonal connections in the central olfactory system of rats. J Comp Neurol 223:177202. CrossRef Medline

Scott JW, McBride RL, Schneider SP (1980) The organization of projections from the olfactory bulb to the piriform cortex and olfactory tubercle in the rat. J Comp Neurol 194:519-534. CrossRef Medline

Sellings LHL, McQuade LE, Clarke PBS (2006) Evidence for multiple sites within rat ventral striatum mediating cocaine-conditioned place preference and locomotor activation. J Pharmacol Exp Ther 317:1178-1187. CrossRef

Shafa F, Meisami E (1977) A horseradish peroxidase study of the origin of central projections to the rat olfaction bulb. Brain Res 136:355-359. Medline

Shepherd GM (1972) Synaptic organization of the mammalian olfactory bulb. Physiol Rev 52:864-917. CrossRef Medline 
Shipley MT, Adamek GD (1984) The connections of the mouse olfactory bulb: a study using orthograde and retrograde transport of wheat germ agglutinin conjugated to horseradish peroxidase. Brain Res Bull 12:669-688. Medline

Shipley MT, Halloran FJ, de la Torre J (1985) Surprisingly rich projection from locus coeruleus to the olfactory bulb in the rat. Brain Res 329:294-299. Medline

Smith DW, Aouad RK, Keil A (2012) Cognitive task demands modulate the sensitivity of the human cochlea. Front Psychol 3:30. CrossRef Medline

Steinfeld R, Herb JT, Sprengel R, Schaefer AT, Fukunaga I (2015) Divergent innervation of the olfactory bulb by distinct raphe nuclei. J Comp Neurol 523:805-813. CrossRef Medline

Sullivan RM, Wilson DA, Leon M (1989) Norepinephrine and learninginduced plasticity in infant rat olfactory system. J Neurosci 9:3998-4006. Medline

Terreros G, Delano PH (2015) Corticofugal modulation of peripheral auditory responses. Front Syst Neurosci 9:134. CrossRef Medline

Wachowiak M, Shipley MT (2006) Coding and synaptic processing of sensory information in the glomerular layer of the olfactory bulb. Semin Cell Dev Biol 17:411-423. CrossRef Medline

Wachowiak M, Wesson DW, Pírez N, Verhagen JV, Carey RM (2009) Low-level mechanisms for processing odor information in the behaving animal. Ann NY Acad Sci 1170:286-292. CrossRef Medline

Wesson DW, Wilson DA (2010) Smelling sounds: olfactory-auditory sensory convergence in the olfactory tubercle. J Neurosci 30: 3013-3021. CrossRef Medline
Wesson DW, Wilson DA (2011) Sniffing out the contributions of the olfactory tubercle to the sense of smell: hedonics, sensory integration, and more? Neurosci Biobehav Rev 35:655-668. CrossRef Medline

White LE (1965) Olfactory bulb projections of the rat. Anat Rec 152:465-479. CrossRef

Wilson DA, Sullivan RM (2011) Cortical processing of odor objects. Neuron 72:506-519. CrossRef Medline

Xia CZ, Adjei S, Wesson DW (2015) Coding of odor stimulus features among secondary olfactory structures. J Neurophysiol 114:736745. CrossRef Medline

Zahm DS, Heimer L (1987) The ventral striatopallidothalamic projection. III. Striatal cells of the olfactory tubercle establish direct synaptic contact with ventral pallidal cells projecting to mediodorsal thalamus. Brain Res 404:327-331. Medline

Zelano C, Bensafi M, Porter J, Mainland J, Johnson B, Bremner E, Telles C, Khan R, Sobel N (2005) Attentional modulation in human primary olfactory cortex. Nat Neurosci 8:114-120. CrossRef Medline

Zhang Z, Liu Q, Wen P, Zhang J, Rao X, Zhou Z, Zhang H, He X, Li J, Zhou Z, Xu X, Zhang X, Luo R, Lv G, Li H, Cao P, Wang L, Xu F (2017a) Activation of the dopaminergic pathway from VTA to the medial olfactory tubercle generates odor-preference and reward. Elife 6. CrossRef Medline

Zhang Z, Zhang $\mathrm{H}$, Wen $\mathrm{P}$, Zhu X, Wang L, Liu Q, Wang J, He X, Wang $\mathrm{H}$, Xu F (2017b) Whole-brain mapping of the inputs and outputs of the medial part of the olfactory tubercle. Front Neural Circuits 11:52. CrossRef Medline 